Fakultas Hukum Universitas Lancang Kuning, Jalan Yos Sudarso KM 8 Rumbai Pekanbaru, Riau, Kode Pos 28266. Telp: (+62761)-51877

E-mail: jurnal.respublica@ac.id

Website: https://journal.unilak.ac.id/index.php/Respublica

\title{
PELAKSANAAN TINDAK PIDANA NARKOTIKA DENGAN TEKNIK UNDERCOVER BUY (PEMBELIAN TERSELUBUNG) BERDASARKAN UNDANG- UNDANG NOMOR 35 TAHUN 2009 TENTANG NARKOTIKA
}

Tesa Amelia Fikri

Polri, Email: tesaamelia.fikri@gmail.com

\begin{tabular}{l} 
Article Info \\
Article History: \\
Received : $01-10-2021$ \\
Revised : 20-01-2021 \\
Accepted : 10-02-2021 \\
Published : 28-05-2021 \\
\hline
\end{tabular}

\section{Keywords:}

Keyword Criminal Act

Keyword Narkotics

Keyword undercover Buy
Informasi Artikel

\section{Histori Artikel:}

Diterima : 01-10-2020

Direvisi : 20-01-2021

Disetujui : 10-02-2021

Diterbitkan : 28-05-2021

\section{Kata Kunci:}

Kata Kunci Tindak Pidana

Kata Kunci Narkotika

Kata Kunci Pembelian

Terselubung

\begin{abstract}
How is the investigation of narcotics crimes using the undercover buy method based on Law Number 35 of 2009 concerning Narcotics? What are the obstacles and what are the efforts to overcome obstacles to the implementation of narcotics crime investigations using the undercover buy method based on Law Number 35 of 2009 concerning Narcotics? the type of research that the author does in this research is a type of sociological legal research. an undercover buy in a narcotics crime investigation where an informant or police officer (under cover) or official. another who is seconded to the police, acts as a buyer in an illicit transaction of buying and selling narcotics. Barriers include internal and external. Efforts made by police investigators to overcome this mine technique by exploiting the weakness of this mine technique in the eyes of the law because of the Narcotics Law of 2009 which is in article 86 paragraph (2) concerning legal evidence.
\end{abstract}

\begin{abstract}
Abstrak
Bagaimana pelaksanaan penyidikan tindak pidana narkotika menggunakan cara undercover buy (pembelian terselubung) berdasarkan Undang-Undang Nomor 35 Tahun 2009 tentang Narkotika? Bagaimana hambatan dan Bagaimana upaya mengatasi hambatan pelaksanaan penyidikan tindak pidana narkotika menggunakan cara undercover buy (pembelian terselubung) berdasarkan Undang-Undang Nomor 35 Tahun 2009 tentang Narkotika? jenis penelitian yang penulis lakukan dalam penelitian ini adalah jenis penelitian hukum sosiologis. terselubung (undercover buy) dalam penyidikan kejahatan narkotika di mana seorang informan atau anggota polisi (di bawah selubung) atau pejabat lain yang diperbantukan kepada polisi, bertindak sebagai pembeli dalam suatu transaksi gelap jual beli narkotika. Hambatan antara lain internal dan eksternal. Upaya yang dilakukan penyidik polri untuk mengatasi teknik ranjau ini dengan memanfaatkan kelemahan Teknik ranjau ini di mata hukum karena adanya Undang-Undang Narkotika tahun 2009 yaitu ada dalam pasal 86 ayat (2) tentang alat bukti yang sah.
\end{abstract}

\section{PENDAHULUAN}

Setiap individu dalam kehidupan bermasyarakat selalu diatur oleh hukum, baik hukum adat maupun hukum positif karena hukum mampu menciptakan perdamaian dan ketertiban dalam kehidupan bermasyarakat. Tujuan hukum 
tersebut sejalan dengan tujuan pembangunan nasional yang termaktub dalam Undang-undang dasar 1945 yaitu melindungi segenap bangsa indonesia dan seluruh tumpah darah Indonesia dan untuk memajukan kesejatraan umum mencerdaskan kehidupan bangsa dan ikut melaksanakan ketertiban dunia yang berdasarkan kemerdekaan, perdamaian abadi dan keadilan sosial. ${ }^{1}$

Perkembangan kemajuan masyarakat yang cukup pesat diiringi dengan pengaruh globalisasi, perkembangan itu selalu diikuti proses penyesuain diri yang kadang-kadang proses tersebut terjadi secara tidak seimbang. Dengan kata lain, pelangaran terhadap norma - norma tersebut semakin sering terjadi dan kejahatan semakin bertambah, baik jenis dan polanya semakin kompleks. Perkembangan masyarakat itu disebabkan karena ilmu pengetahuan dan pola pikir masyarakat yang semakin maju.

Masyarakat berusaha mengadakan pembaharuan pembaharuan di segala bidang. Namun kemajuan teknologi tidak selamanya berdampak positif kadang kala berdampak negatif. Berkembangnya pengaruh teknologi maka semakin banyak terjadi kejahatan dengan modus operandi yang canggih. Ini merupakan tantangan bagi para penegak hukum untuk menciptakan penanggulangannya, khususnya dalam narkotika dan obat obat terlarang

Peredaran Narkotika di Indonesia sudah merajalela dan sangat meresahkan kita semua, masuknya barang haram tersebut ke Indonesia, karena dianggap pasar yang cukup menguntungan bagi para bandar dan pengedar baik dalam dan luar negeri. Inilah yang menjadi keprihatinan serta perhatian serius bagi Pemerintah Presiden RI Joko Widodo tidak memberikan grasi kepada bandar-bandar tersebut dan menerima hukuman mati, ini harus dilakukan kalau memang Indonesia mau mencegah barang tersebut masuk di Indonesia dan membuat efek jera. Presiden menyatakan Indonesia sudah gawat Narkotika sebab, hingga kini belum ada tanda-tanda penurunan peredaran gelap dan penyalahgunaan narkotika. Bahkan tahun depan pengguna narkoba di Indonesia diprediksi mencapai 5 juta jiwa. ${ }^{2}$

Penyalahgunaan narkotika semakin meningkat di Indonesia. Menurut Badan Narkotika Nasional (BNN), berdasarkan data dari UNODC (United Nations Office On Drugs Crimes) di dunia ada 315 juta orang usia produktif atau berumur 15 sampai 65 tahun yang

1 Undang- Undang dasar 1945 dan perubahannya + struktur ketatanegaran, edisi kedelapan (Yokyakarta: Indonesia tera, 2011), hlm 5

${ }_{2}^{2}$ https://www.rappler.com/indonesia/137677-pidato-jokowi-hari-anti-narkoba-internasional 
menjadi pengguna narkotika dan ada 200 juta orang meninggal dunia setiap tahunnya akibat narkotika. $^{3}$

Transaksi dan peredaran narkotika yang dilakukan oleh pelaku kejahatan terorganisir (Organized Crime) ternyata terus meningkat sehingga perlu diperlukan berbagai macam upaya untuk untuk melindungi masyarakat dari bahaya penyalahgunaan narkotika. Penyalahguna narkotika menduduki rangking 20 dunia sebagai penyebab angka kematian dan rangking ke 10 di negara sedang berkembang, termasuk Indonesia. Penyalahguna narkotika diketahui sangat rentan dan mudah terjangkit HIV, Hepatitis dan Tubercolis, yang kemudian dapat menular ke masyarakat umum.

Di Indonesia hukum yang mengawasi dan mengendalikan penggunaan narkotika serta menanggulangi penyalahgunaan narkotika dan perawatan para korbannya dikenal dengan hukum narkotika. ${ }^{4}$ Hukum yang mengatur tentang narkotika ini sangatlah diperlukan mengingat penyebarannya yang semakin meningkat di berbagai daerah baik secara nasional maupun transnasional. Hukum yang mengatur mengenai penggunaan Narkotika diawali dengan dibuatnya Undang Undang No 9 Tahun 1976. Seiring dengan perkembangannya kemudian diperbaharui dan diganti lagi dengan Undang Undang No 35 Tahun 2009 karena Undang Undang yang lama tersebut dianggap tidak cukup lagi dalam menangani penyebaran dan peredaran gelap Narkotika.

Setelah dikeluarkannya Undang-Undang No. 35 Tahun 2009, diharapkan dapat mencegah dan menekan meningkatnya peredaran serta penggunaan narkotika diwilayah Indonesia. Dengan Undang-Undang yang mengkhususkan mengenai narkotika, maka semua pihak berharap dapat berjalan dengan baik dan sanksi yang ada dapat ditetapkan secara adil bagi pelaku tindak pidana narkotika.Undang-Udang narkotika sangat perlu untuk ditegakkan karena pengaruh narkotika yang sangat besar terhadap kelangsungan hidup suatu bangsa terutama bagi generasi muda penerus bangsa.

Berkaitan dengan hal itu diatas, berbicara mengenai aparat penegak hukum hampir sepenuhnya akan menyinggung soal penyelidikan dan penyidikan. Penyidikan dilakukan sebelum penyidikan. ${ }^{5}$

\footnotetext{
3 http://nasional.news.viva.co.id/news/read/516363-bnn--pengguna-narkoba-di-indonesia-capai-4-2-jutaorang

${ }^{4}$ Hari Sasangka, 2003, Narkotika dan Psikotropika dalam Hukum Pidana, (Bandung: Mandar Maju, 2003), hlm. 4.

5 Laden Marpaung, Proses Penanganan Perkara Pidana (penyelidikan dan penyidikan) edisi kedua (Jakarta: Sinar Grafika, 2011), hlm. 6.
} 
Penyelidik berfungsi untuk mengetahui dan menentukan peristiwa apa yang sesunguhnya terjadi dan bertugas membuat berita acara serta laporannya yang nantinya menjadi dasar permulaan penyidik. Oleh karena itu, maka tampak jelas bahwa penyelidikan adalah bagian dari tahap penyidakan yang merupakan satu tahap yang harus dilalui dalam pengajuan perkara pidana kemuka persidangan. ${ }^{6}$

Undang-Undang hukum acara pidana pada pasal 1 butir 5, yang dimaksud dengan penyelidikan adalah serankaian tindakan penyelidik untuk mencari dan menemukan suatu peristiwa yang diduga sebagai tindak pidana guna menentukan dapat atau tidaknya dilakukan penyidikan menurut cara yang diatur dalam Undang-Undang ini. ${ }^{7}$

Pasal 1 angka 1 Undang-Undang No 35 Tahun 2009 tentang Narkotika pengertian Narkotika adalah: zat atau obat yang berasal dari tanaman atau bukantanaman, baik sintesis maupun semi sintesis yang dapat menyebabkan penurunan atau perubahan kesadaran, hilangnya rasa, mengurangi sampai menghilangkan rasa nyeri, dan dapat menimbulkan ketergantungan, yang dibedakan kedalam golongan-golongan sebagaimana terlampir dalam Undang-Undang ini.

Dari pengertian diatas bahwa penyelidikan merupakan tindakan tahap pertama untuk memulai penyidikan, namun pada tahap penyelidikan yang harus ditekankan adalah mencari dan menemukan suatu peristiwa yang dianggap atau diduga sebagai tindak pidana. Jadi dapat disimpulkan bahwa sebenarnya penyelidikan itu adalah penentuan suatu perbuatan dapat dikatakan sebagi suatu tindak pidana atau tidak, ketika suatu perbuatan tersebut dinggap suatu tindak pidana baru dapat dilakukan proses penyidikan.

Penyalahgunaan narkotika tidak lagi merupakan kejahatan tanpa korban (victimless crime), melainkan sudah merupakan kejahatan yang memakan banyak korban dan bencana berkepanjangan kepada seluruh umat manusia di dunia ${ }^{8}$. Pada dua dasawarsa terakhir, penggunaan dan pengedaran nakotika secara illegal diseluruh dunia menunjukkan peningkatan yang tajam serta mewabah merasuki semua bangsa, serta meminta banyak korban.

\footnotetext{
${ }^{6}$ Ibid, hlm 7

${ }^{7}$ Andi Hamzah, KUHP dan KUHAP (Jakarta: Rineka Cipta, 2007), hlm 230

${ }^{8}$ Badan Narkotika Nasional, 2011, Pedoman Pencegahan Penyalahgunaan Narkoba Bagi Pemula, Jakarta: Badan Narkotika Nasional Republik Indonesia, hlm 4.
} 
Salah satu teknik yang digunakan penyidik dalam melakukan penyidikan tindak pidana narkotika yaitu teknik pembelian terselubung. Penyidik sendiri dan atau menggunakan orang lain melakukan pembelian narkotika dengan diawasi kemudian menangkap pelaku beserta barang buktinya. Kewenangan penyidik Polri untuk melakukan pembelian terselubung (undercover buy) terdapat pada Pasal 75 hurif j dan Pasal 79 Undang-Undang Nomor 35 Tahun 2009 tentang Narkotika yaitu melakukan teknik penyidikan pembelian terselubung dan penyerahan di bawah pengawasan.

Ketentuan perundang-undangan yang mengatur masalah narkotika telah disusun dan diberlakukan, namun demikian kejahatan yang menyangkut tentang narkotika belum dapat diredakan. Dalam banyak kasus terakhir, banyak bandar bandar dan pengedar yang tertangkap dan mendapat sanksi berat, namun pelaku lain seperti tidak mengacuhkannya bahkan lebih cenderung untuk memperluas daerah operasinya ${ }^{9}$. Melihat peredaran narkotika yang semakin berkembang di wilayah hukum Polresta Pekanbaru hal terlihat dari pengungkapan kasus narkotika dari tahun 2015 berjumlah 77 dengan jumlah tersangka 109, tahun 2016 berjumlah 133 kasus dengan jumlah tersangka 236, dan tahun 2017 berjumlah 185 kasus dengan jumlah tersangkanya 125. Sedangkan untuk wilayah hukum Polsek Senapelan pekanbaru kasus narkotika tahun 2016 berjumlah 18 kasus, tahun 2017 berjumlah 28 kasus dan tahun 2018 berjumlah 25 kasus, tentunya membuat masyarakat semakin resah. Dengan demikian para pihak terkait terutama pihak kepolisian tentunya harus meningkatkan penanggulangan untuk mengatasi permasalahan tersebut.

Dalam penanggulangan terhadap penyalahgunaan dan peredaran narkotika tersebut, salah satunya adalah dilakukannya teknik pembelian terselubung (undercover buy). Tindakan Pembelian Terselubung (undercover buy) diatur dalam Pasal 75 huruf J Undang-Undang No. 35 Tahun 2009 Narkotika. Sebagaimana yang dinyatakan dalam petunjuk lapangan No.Pol. Juklap/04/VIII/1983 pembelian terselubung (undercover buy) adalah suatu teknik khusus dalam penyidikan kejahatan narkotika dan precursor narkotika, dimana seorang informan atau anggota polisi (di bawah selubung), bertindak sebagai pembeli dalam suatu transaksi gelap jual beli narkotika, dengan maksud pada saat terjadi hal tersebut si penjual atau perantara atau

\footnotetext{
${ }^{9}$ Dikdik M. Arief Mansur \& Elisatris Gultom, Urgensi Perlindungan KorbanKejahatan (Antara Norma dan Realita), (Jakarta : Raja Grafindo Persada, 2007), hlm 101
} 
orang-orang yang berkaitan supply narkotika dan precursor narkotika dapat ditangkap beserta barang bukti apa adanya ${ }^{10}$.

Berdasarkan latar belakang, penulis menyimpulkan, Bagaimana pelaksanaan penyidikan tindak pidana narkotika menggunakan cara undercover buy (pembelian terselubung) berdasarkan Undang-Undang Nomor 35 Tahun 2009 tentang Narkotika? Bagaimana hambatan pelaksanaan penyidikan tindak pidana narkotika menggunakan cara undercover buy (pembelian terselubung) berdasarkan Undang-Undang Nomor 35 Tahun 2009 tentang Narkotika? Bagaimana upaya mengatasi hambatan pelaksanaan penyidikan tindak pidana narkotika menggunakan cara undercover buy (pembelian terselubung) berdasarkan UndangUndang Nomor 35 Tahun 2009 tentang Narkotika? Adapun jenis penelitian yang penulis lakukan dalam penelitian ini adalah jenis penelitian hukum sosiologis yang membahas tentang pelaksanaan penyidikan tindak pidana narkotika menggunakan cara undercover buy (pembelian terselubung) berdasarkan Undang-Undang Nomor 35 Tahun 2009 tentang Narkotika

\section{Wewenang Penyidik berdasarkan Undang-Undang Nomor 35 Tahun 2009 Tentang Narkotika}

Penyidik pada Undang-Undang Nomor 35 Tahun 2009 tentang Narkotika, memberikan kewenangan penyidikan terhadap penyidik Badan Narkotika Nasional. Dalam Pasal 71 Undang-Undang Nomor 35 Tahun 2009 menyatakan bahwa alam melaksanakan tugas pemberantasan penyalahgunaan dan peredaran gelap Narkotika dan Prekursor Narkotika, BNN berwenang melakukan penyelidikan dan penyidikan penyalahgunaan dan peredaran gelap Narkotika dan Prekursor Narkotika. Lebih lanjut, dalam Pasal 72 dalam undangundang tersebut memberikan pengaturan tentang penyidik BNN, sebagai berikut :

1. Kewenangan sebagaimana dimaksud dalam Pasal 71 dilaksanakan oleh penyidik BNN.

2. Penyidik BNN sebagaimana dimaksud pada ayat (1) diangkat dan diberhentikan oleh Kepala BNN.

3. Ketentuan lebih lanjut mengenai syarat dan tata cara pengangkatan dan pemberhentian penyidik BNN sebagaimana dimaksud pada ayat (2) diatur dengan Peraturan Kepala BNN.

Mengenai kewenangan penyidik BNN diatur dalam Pasal 75 Undang-Undang Nomor 35 Tahun 2009 tentang Narkotika, Kewenangan lain yang dimiliki oleh penyidik BNN diatur

10 Petunjuk Lapangan No. Pol. Juklap/04/VIII/1983, taktik dan teknik pembelian narkotika dan psikotropika 
dalam Pasal 80 Undang-Undang Nomor 35 Tahun 2009 tentang Narkotika, bahwa penyidik BNN sebagaimana dimaksud dalam Pasal 75.

Kewenangan penyidikan Narkotika sebagaimana diatur dalam Undang-Undang Nomor 35 Tahun 2009 tentang Narkotika tidak hanya kepada diberikan penyidik BNN, tetapi juga kepada penyidik Polri sebagaimana diatur dalam Pasal 81, yang menyatakan bahwa penyidik Kepolisian Negara Republik Indonesia dan penyidik BNN berwenang melakukan penyidikan terhadap penyalahgunaan dan peredaran gelap Narkotika dan Prekursor Narkotika berdasarkan undang-undang ini.

Maksud dari Pasal 81 di atas, bahwa penyidik Polri dalam melakukan upaya pemberantasan Narkotika juga memiliki kewenangan penyidikan sebagaimana kewenangan penyidikan oleh penyidik BNN. Tidak ada yang lebih superior antara penyidik Polri dan penyidik BNN, keduanya memiliki kewenangan yang sama, dan saling bekerjasama satu sama lain dalam upaya pemberantasan penyalahgunaan dan peredaran gelap Narkotika dan Prekursor Narkotika. ${ }^{11}$ Dengan demikian, sejak berlakunya Undang-Undang Nomor 35 Tahun 2009 tentang Narkotika, maka Badan Narkotika Nasional mempunyai kewenangan dalam melakukan penyelidikan dan penyidikan terhadap perkara tindak pidana Narkotika menurut tata cara sebagaimana diatur baik dalam hukum pidana materiil maupun formil yang harus dipatuhi dalam proses penanganan perkara penyalahgunaan dan peredaran gelap Narkotika dan Preskursor Narkotika di wilayah Republik Indonesia. ${ }^{12}$

\section{c. Pengertian Narkoba}

Menurut batasan WHO (1969) yang dimaksud obat (drug) adalah setiap zat yang apabila masuk ke dalam organisme hidup akan mengadakan perubahan pada satu atau lebih fungsi-fungsi organ tubuh. Narkoba (Narkotika dan obat-obat berbahaya) ialah zat kimiawi yang mampu mengubah pikiran, perasaan, fungsi mental dan prilaku seseorang. Apabila berbagai jenis obat narkotika, alkohol serta zat-zat lainnya yang memabukkan ini disalahgunakan untuk tujuan di luar pengobatan, akan mengubah kerja saraf otak, sehingga si pemakai berpikir, berperasaan dan berprilaku tidak normal. ${ }^{13}$ Sebagai zat adiktif atau yang bias menimbulkan efek kecanduan. Pemakainya sulit untuk dikontrol, setelah setagihan (addited)

11 A.R Sujono dan Bony Daniel, 2013, Komentar \& Pembahasan Undang-Undang Nomor 35 Tahun 2009 tentang Narkotika, (Sinar Grafika : Jakarta), 2013, hlm 154.

12 Ibid, Hlm 132-133.

${ }^{13}$ BNN, "Materi Advokasi Pencegahan Narkoba". (Jakarta: BNN. 2005) hlm. 7 
pemakai narkotika akan sampai pada tingkat yang paling parah yaitu ketergantungan (dependence). Narkotika adalah zat atau obat yang berasal dari tanaman atau bukan tanaman, baik sintetis maupun semisintetis yang dapat menyebabkan penurunan atau perubahan kesadaran, hilangnya rasa, mengurangi sampai menghilangkan rasa nyeri dan dapat menimbulkan ketergantungan yang dibedakan ke dalam golongan-golongan sebagaimana dijelaskan dalam Undang-Undang Nomor 35 Tahun 2009 tentang Narkotika. ${ }^{14}$ Menurut Undang-Undang Narkotika dibagi menurut potensi menyebabkan ketergantungannya sebagai berikut: ${ }^{15}$

a) Narkotika golongan I, yakni berpotensi sangat tinggi menyebabkan ketergantungan.

Tidak digunakan untuk terapi. Contoh: Heroin, Kokain, dan Ganja. Putaw adalah heroin tidak murni merupakan bubuk.

b) Narkotika golongan II, yakni berpotensi tinggi menyebabkan ketergantungan. Digunakan pada terapi sebagai pilihan terakhir. Contoh: Morfin dan Petidin.

c) Narkotika golongan III, yakni berpotensi ringan menyebabkan ketergantungan dan banyak digunakan dalam terapi. Contoh : Kodean.

\section{Pelaksanaan penyidikan tindak pidana narkotika menggunakan cara undercover buy (pembelian terselubung) berdasarkan Undang-Undang Nomor 35 Tahun 2009 tentang Narkotika}

Pembelian terselubung (undercover buy) sebagai suatu metode yang dilakukan penyidik dalam tindak pidana yang pengertiannya dalam petunjuk lapangan No. Pol. Juklap/04/VIII/1983 disebutkan bahwa: "Pembelian terselubung atau undercover buy merupakan suatu teknik khusus dalam penyelidikan kejahatan narkotika, dimana seorang informan atau anggota polisi (dibawah selubung), atau pejabat lain yang diperbantukan kepada polisi (di bawah selubung), bertindak sebagai pembeli dalam suatu transaksi gelap jual beli narkotika, dengan maksud pada saat terjadi hal tersebut, si penjual atau perantara atau

\footnotetext{
${ }^{14}$ Lihat Undang-Undang Nomor 35 Tahun 2009 Pasal 1 Angka 1

${ }^{15}$ Tim Penyusun Badan Narkotika Nasional Republik Indonesia, 2007, Pencegahan Penyalahgunaan Narkoba Sejak Dini, (Jakarta : BNN RI), hlm 29-29
} 
orang-orang yang berkaitan dengan suplai narkotika dapat ditangkap beserta barang bukti yang ada padanya. ${ }^{16}$

Pembelian terselubung sendiri, sepertinya hal ini dapat dipersamakan dengan penjebakan yang direstui oleh Undang-Undang. Namun, yang perlu diketahui disamping kewajiban adanya perintah dari atasan penyidik, sepatutnya pembelian terselubung menargetkan pada penangkapan penjual narkotika dan terutama dalam skala besar dan tidak menyasar pada tindak pidana narkotika dalam skala kecil. ${ }^{17}$

Persoalan dengan teknik pembelian terselubung adalah tidak adanya uraian lebih lanjut di dalam Undang-Undang No. 35 tahun 2009 tentang Narkotika mengenai pembelian terselubung dan penyerahan diawasi. Kedua jenis operasi ini rentan terhadap penyelewengan. Seseorang tidak dapat mengonfirmasi apakah sebuah "penjebakan" yang terjadi padanya benar merupakan pembelian terselubung ataupun penyerahan diawasi. Dalam contoh di pola keempat tersebut, bagaimana dapat memastikan bahwa agent telah selesai menjalani masa tugasnya, sehingga tidak menyalahgunakan jabatan sebagai undercover agent. ${ }^{18}$ Ketika seseorang dijebak dengan pembelian terselubung, penjebakan tersebut memiliki legitimasinya dalam 2 (dua) hal yaitu pertama, orang tersebut memang memiliki niat melakukan tindak pidana. Kedua, teknik pembelian terselubung untuk menangkap orang tersebut adalah operasi yang sah secara hukum.

Menurut Ipda Budi Winarko, ST Tindak pidana narkotika, penyidikan dan penyidikan di mulai dari adanya informasi dari informan. Di mana atas informasi yang diberikan oleh informan tersebut kemudian dilakukanlah penyelidikan atas kebenaran informasi tersebut. Dalam tindak pidana narkotika, informan biasanya berasal dari informan yang dahulunya adalah bekas pemakai atau orang yang mengenal betul dunia narkotika. ${ }^{19}$

${ }^{16}$ Wishnu Kurniawan dan Tanty Susanti, 2015, Penerapan Ultimum Remedium Terhadap Penanganan Tindak Pidana Narkoba (Studi Wilayah Polresta Barelang Batam), Journal of Judical Review Vol.XVII No.3 Desember 2015, hlm 42

${ }^{17}$ Ricky Gunawan, Kajian dan Anotasi Peradilan Putusan Ket San: Menelusuri Fenomena Penjebakan Dalam Kasus Narkotika, Dictum Edisi 1 - Oktober 2012,hlm 25

${ }^{18}$ Ibid

${ }^{19}$ Hasil wawancara dengan Ipda Budi Winarko, ST Kanit. Reskrim, Polsek Senapelan, 10 April 2019, Pukul 14.00 Wib bertempat di Polsek Senapelan 
Menurut pendapat pelaku penyalahgunaan narkotika dengan inisial $\mathrm{HN}$ ada beberapa motifasi sehingga orang yang pernah ketagihan ini memberikan informasi atau keterangan kepada penyidik yaitu $:^{20}$

1. Karena faktor uang yaitu orang yang memberikan keterangan kepada polisi terdorong karena susah atau karena akan mendapat hadiah langsung.

2. Karena kesadaran dari bekas pecandu narkotika

3. Menurut pendapat Informan inisial SB karena didorong oleh rasa aman. ${ }^{21}$ Pengaturan penyidik dalam Undang-Undang Nomor 35 Tahun 2009 tentang Narkotika diatur sebagai berikut:

a. Penyidik dari Badan Narkotika Nasional (BNN) yang diatur mulai Pasal 75 sampai dengan Pasal 81 Undang-Undang No. 35 Tahun 2009 tentang Narkotika

b. Penyidik Pegawai Negeri Sipil (PPNS) tertentu yang diatur mulai Pasal 82 sampai dengan Pasal 86 Undang-Undang Nomor 35 Tahun 2009 tentang Narkotika

c. Penyidik Kepolisian Negara Republik Indonesia diatur mulai Pasal 87 sampai dengan Pasal 95 Undang-Undang Nomor 35 Tahun 2009 tentang Narkotika. ${ }^{22}$

Pemeriksaan tindak pidana narkotika biasanya dilakukan setelah menerima informasi/ laporan atau dugaan mengenai telah terjadinya suatu tindak pidana narkotika. Pemeriksaan tersebut dilakukan oleh penyidik dengan melakukan tindakan pertama ditempat kejadian perkara (locus delicti) yaitu dengan mengadakan penelitian untuk menemukan barang-barang bukti yang ada ditempat kejadian. Untuk itu maka penyidik akan berupaya untuk mendapatkan orang yang diduga melakukan tindak pidana narkotika tersebut, dengan upaya menanyakan identitas dari orang yang diduga terlibat dan apabila perlu dilakukan penangkapan, penahanan, penggeledahan, dan penyitaan. Jadi pada dasarnya pemeriksaan tindak pidana narkotika itu dimulai sejak diketahuinya telah terjadi tindak pidana di suatu tempat, sedangkan pemeriksaan terhadap pelaku tindak pidana narkotika dilakukan setelah penangkapan. ${ }^{23}$

\footnotetext{
${ }^{20}$ Hasil wawancara dengan Pelaku inisial HN tahanan Polsek Senapelan, 18 Mei 2019, Pukul 13.00 Wib bertempat di Polsek Senapelan

${ }^{21}$ Hasil wawancara dengan informan inisial SB, 18 Mei 2019, Pukul 14.40 Wib bertempat di Polsek Senapelan

22 Siswanto, S. 2012, Politik Hukum Dalam Undang-Undang Narkotika, Cetakan Pertama, (Rineka Cipta : Jakarta), 2012, hlm. 24

${ }^{23}$ Moh. Taufik Makaro, dkk. 2003, Tindak Pidana Narkotika, (Ghalia Indonesia : Jakarta), hlm 62
} 
Lembaga kepolisian memiliki peranan yang sangat besar dalam kehidupan masyarakat ataupun dalam dimensi kenegaraan oleh kerenanya dengan ruang lingkup yang sangat luas di dalam tubuh kepolisian harus ada pemberian tugas yang jelas.

Peran penting pihak kepolisian dalam tugasnya memberantas kasus kejahatan terkait narkotika harus didukung dengan baik walaupun angka-angka kasus tersebut tetap meningkat. Terungkapnya kasus-kasus, di satu sisi memang dapat menjadi indikator meningkatnya kerja polisi dalam memburu sindikat peredaran narkotika namun di sisi lain dapat memberi petunjuk betapa kebijakan pemerintah saat ini lemah dalam menghadapi peredaran narkotika tersebut.

Menurut Aiptu Candra upaya mengatasi penyalahgunaan narkotika di wilayah hukum Polsek Senapelan melakukan patnership building yaitu teknik pembelian terselubung yang diawasi. Dalam teknik ini kepolisian masih melibatkan orang umum yang ingin dan dapat bekerjasama dengan kepolisian dalam transaksi ini berawal dari adanya infornasi masyarakat dan diduga adanya tempat yang dijadikan sebagai transaksi dan peredaran narkotika salah satunya melalui jasa penitipan. Sebelumnya pihak kepolisian melakukan koordinasi dalam mengungkap jaringan narkotika. Apabila ditemukan bukti adanya tindak pidana narkotika, maka polisi langsung melakukan proses penindakan di Tempat Kejadian Perkara (TKP), dengan melakukan penggeledahan, penyitaan barang bukti, dan penangkapan. ${ }^{24}$

Teknik pembelian terselubung merupakan teknik pengungkapan tindak pidana narkotika yang dibenarkan oleh undang-undang, yakni Undang - Undang No.35 tahun 2009 tentang Narkotika. Berdasarkan petunjuk lapangan No.Pol. Juklap/04/VIII/1983 pengertian dari teknik pembelian terselubung merupakan suatu teknik khusus penyidikan dalam pengungkapan kejahatan narkotika dan Psikotropika, di mana seorang informan atau anggota polisi (di bawah selubung), atau pejabat lain yang diperbantukan kepada polisi (dibawah selubung), bertindak sebagai pembeli dalam suatu transaksi gelap jual beli narkotika dan psikotropika, dengan maksud pada saat terjadi hal tersebut, si penjual atau perantara atau orang-orang yang berkaitan dengan suplai narkotika dan psikotropika dapat ditangkap beserta barang bukti yang ada pada tempat kejadian perkara. ${ }^{25}$

\footnotetext{
${ }^{24}$ Hasil wawancara dengan Aiptu Candra, Katim Buser, Polsek Senapelan, 10 April 2019, Pukul 09.30 Wib bertempat di Polsek Senapelan

${ }^{25}$ I Putu Wisnu Nugraha, dkk. 2016, Peranan Teknik Undercover Buy Dalam Pengungkapan Tindak Pidana Narkotika (Studi di Polresta Denpasar), Artikel, Fakultas Hukum Universitas Udayana, 2016, hlm 3
} 
Menurut Bripka Jatmiko upaya menghindari terjadi penyimpangan dalam pelaksanaan pembelian terselubung yang dilakukan oleh penyidik guna mengurangi penyimpangan tersebut, maka ada pengaturan bahwa pelaksanaan pembelian terselubung ini harus sesuai dengan surat perintah tertulis dari atasan. Hal ini berguna untuk menghindari penyidik yang melakukan penyimpangan yang mengatasnamakan diskresi dalam pelaksanaan pembelian terselubung ini. ${ }^{26}$

Menutut pelaku penyalahgunaan narkotika dengan inisial $\mathrm{H}$ metode pembelian terselubung (undercover buy) dalam penyidikan kejahatan narkotika di mana seorang informan atau anggota polisi (di bawah selubung) atau pejabat lain yang diperbantukan kepada polisi, bertindak sebagai pembeli dalam suatu transaksi gelap jual beli narkotika ${ }^{27}$, dan dengan maksud pada saat terjadi hal tersebut, si penjual atau perantara atau orang-orang yang berkaitan dengan suplai narkotika dapat ditangkap beserta barang bukti yang ada padanya.

Menurut Brigadir Eko Setiawan penyidikan tindak pidana narkotika dengan metode pembelian secara terselubung (undur cover buy), diatur dalam Undang-Undang Nomor 35 Tahun 2009 tentang Narkotika dalam Pasal 75 dan 79, akan tetapi dalam pelaksanaannya teknik penyidikan dalam pelaksanaannya harus mendapat surat perintah dari pimpinan karena tanpa adanya surat perintah ini, maka penyelidikan menggunakan metode terselubung (under cover buy) dianggap tidak sah. ${ }^{28}$

Menurut Informan dengan inisial IP sebelum diadakannya pembelian terselubung (undercover buy), maka diadakan pertemuan dan/atau perundingan dengan pengedar narkotika untuk memungkinkannya dilakukan pembelian terselubung, jika dimungkinkan pembelian terselubung dilakukan lebih dari satu orang, hal ini tergantung kepada situasi dan kondisi $^{29}$. Menurut Ipda Budi Winarko, ST setelah dilakukan berupa transaksi dan dari pihak lawan tidak terdapat kecurigaan terhadap orang terselubung, selanjutnya ditentukan saat yang tepat untuk melakukan operasi terselubung. Dalam menentukan lokasi perlu diperhatikan, antara lain:

\footnotetext{
${ }^{26}$ Hasil wawancara dengan Bripka Jatmiko, anggota Reskrim, Polsek Senapelan, 10 April 2019, Pukul 11.00 Wib bertempat di Polsek Senapelan

${ }^{27}$ Hasil wawancara dengan pelaku inisial H, Tahanan Polsek Senapelan, 18 Mei 2019, Pukul 13.10 Wib bertempat di Polsek Senapelan

${ }^{28}$ Hasil wawancara dengan Brigadir Eko Setiawan, anggota Reskrim, Polsek Senapelan, 10 April 2019, Pukul 11.40 Wib bertempat di Polsek Senapelan Senapelan

${ }^{29}$ Hasil wawancara dengan pelaku informan IP, 18 Mei 2019, Pukul 13.20 Wib bertempat di Polsek
} 
a. Menurut pendapat pelaku inisial RM, lokasi harus memungkinkan dilakukannya pengawasan terhadap gerak-gerik pelaku dan memungkinkan dilakukannya pengamanan terhadap undercover, ${ }^{30}$ uang transaksi dan dihindari tempat yang terbuka atau terlalu ramai, sehingga jika terjadi situasi yang tidak memungkin polri dapat bergerak cepat.

b. Menurut pendapat pelaku inisial TR, lokasi memungkinkan dipergunakannya alat-alat komunikasi dan deteksi, baik untuk mengawasi pelaku maupun untuk kepentingan komunikasi untuk koordinasi sesama anggota. ${ }^{31}$

c. Lokasi harus dikuasai sejak dini, sehingga memungkinkannya dilakukan usaha pengamanan dan menghindari kontra penyelidikan pihak lawan. ${ }^{32}$

Menurut Aiptu Aries Tamsudarto alasan penyidik menggunakan teknik pembelian terselubung (undercover buy) tindak pidana narkotika, karena tindak pidana narkotika merupakan kejahatan tanpa korban. Dengan tidak adanya korban, maka tidak akan ada orang sebagai korban yang akan melaporkan tentang tindak pidana narkotika. Teknik yang digunakan penyelidik dalam melakukan pembelian terselubung adalah mengumpulkan informasi dengan menggunakan informan dan melakukan pembelian terselubung dengan menggunakan kurir, guna mendukung pelaksanaan teknik pembelian terselubung (undercover buy) dengan melakukan observasi, surveillance,undercover agent (penyusupan agen), penyerahan narkotika dan psikotropika yang dikendalikan dan direncana pelaksanaan penggerebekan. ${ }^{33}$

Data Tabel Penyalahgunaan Narkotika di Wilayah Hukum Polsek Senapelan

\begin{tabular}{|c|l|c|c|}
\hline NO & TAHUN & $\begin{array}{c}\text { PENYIDIKAN } \\
(\mathrm{P} 21)\end{array}$ & PENYELIDIKAN \\
\hline 1 & 2018 & 19 & 2 \\
\hline 2 & 2019 (SAMPAI BULAN MEI) & 4 & - \\
\hline \multicolumn{2}{|c|}{ JUMLAH } & $\mathbf{2 3}$ & $\mathbf{2}$ \\
\hline
\end{tabular}
Senapelan

${ }^{30}$ Hasil wawancara dengan pelaku inisial RM, 21 Mei 2019, Pukul 11.20 Wib bertempat di Polsek

${ }^{31}$ Hasil wawancara dengan pelaku inisial TR, 21 Mei 2019, Pukul 11.40 Wib bertempat di Polsek Senapelan

${ }^{32}$ Hasil wawancara dengan Ipda Budi Winarko, ST Kanit. Reskrim, Polsek Senapelan, 10 April 2019, Pukul 14.00 Wib bertempat di Polsek Senapelan

${ }^{33}$ Hasil wawancara dengan Aiptu Aries Tamsudarto, Anggota Reskrim, Polsek Senapelan, 10 April 2019, Pukul 15.00 Wib bertempat di Polsek Senapelan 
Menurut Ipda Budi Winarko, ST anggota Unit Reskrim Polsek Senapelan mempunyai tugas pokok dalam menangani kasus-kasus penyalahgunaan narkotika, yaitu dengan melakukan :

\section{Penyidikan.}

Berawal dari adanya informan dan diduga adanya tempat yang dijadikan sebagai transaksi dan peredaran narkotika salah satunya melalui jasa penitipan. Sebelumnya pihak kepolisian melakukan kerjasama atau koordinasi dalam mengungkap jaringan narkotika.

\section{Penindakan.}

Apabila ditemukan bukti adanya tindak pidana narkotika, maka polisi langsung melakukan proses penindakan di tempat kejadian perkara, dengan melakukan penggeledahan, penyitaan barang bukti, dan penangkapan terhadap pelaku tindak pidana

3. Penyidikan.

Para pelaku tindak pidana narkotika dan psikotropika akan dilakukan pemeriksaan lebih lanjut, yaitu dilakukannya proses penyidikan dengan dibuatnya Berita Acara Pemeriksaan (BAP) saksi dan tersangka serta dilakukan Tes Barang Bukti dengan Narco Pouch Taskit. ${ }^{34}$ Menurut Informan inisial Z, guna menjamin keberhasilan dari operasi pembelian terselubung (undercover buy) dan penyerahan yang diatur (controlled delivery) ini haruslah didahului oleh perencanaan yang matang. Perencanaan ini meliputi beberapa faktor :

a. Jumlah orangnya, macam dan lamanya jenis surveillance, macam dari pembelian yang harus dilakukan dan macam-macam keputusan lainnya yang tak dapat dihindarkan harus menggunakan tenaga manusia.

b. Uang, karena seringkali berhasilnya penangkapan perdagangan Narkotika dan Psikotropika, karena membeli narkotika dan psikotropika tersebut/memamerkan jumlah uang $^{35}$ untuk menarik pengedar narkotika dan psikotropika di mana anggaran untuk melakukan operasi narkotika dan psikotropika harus memadai.

c. Waktu strategi untuk mengamati dan memperlajari tersangka juga berbeda maka waktu yang disediakan untuk operasi narkotika dan psikotropika haruslah cukup. Lebih baik menunda suatu rencana operasi narkotika dan psikotropika bilamana waktu yang tidak

\footnotetext{
${ }^{34}$ Hasil wawancara dengan Ipda Budi Winarko, ST Kanit. Reskrim, Polsek SenapelaPukul 14.00 Wib bertempat di Polsek Senapelan

${ }^{35}$ Hasil wawancara dengan Informan inisial Z, Tahanan Polsek Senapelan, 18 Mei 2019, Pukul 14.20 Wib bertempat di Polsek Senapelan
} 
memadai daripada gagal dalam melakukan tindak, jelas disini bahwa gerak tersangka adalah merupakan faktor utama dimana penyidik menentukan waktu banyak.

d. Alat terutama untuk melaksanakan operasi survellance, petugas harus mempunyai alat yang memadai. Alat-alat ini terdiri dari binokular transmitter tubuh, teropong malam, dan senja//ta khusus.

e. Dan menurut Aiptu Candra bantuan hukum juga perlu dipersiapkan dalam penyidikan dan banyaknya hal-hal teknis, karena penyelesaian kasus seringkali terlupakan hal-hal yang sebenarnya perlu diambil, maka seorang penyidik narkotika dan psikotropika perlu ditunjang oleh seorang ahli hukum bilamana ada. Dan bila peraturan-peraturan hukum dapat diambil dari kantor kejaksaan, maka penyidik dapat mempelajari dengan seksama. ${ }^{36}$

Pada kasus narkotika dan psikotropika, maka perencanaan yang baik akan menentukan operasi yang baik pula. Sehingga usaha yang dilakukan sebelumnya akan dapat dinikmati keberhasilannya dengan perencanaan yang matang. Kegagalan dalam operasi pembelian terselubung dalam tindak pidana narkotika dan psikotropika tidak hanya akan mengganggu keamanan dan ketertiban di dalam masyarakat, akan tetapi juga akan membahayakan orangorang yang terlibat dalam operasi tersebut.

Tingkat keberhasilan Polsek Senapelan dalam melakukan metode pembelian terselubung (undercover buy) guna mengungkap kasus penyalahgunaan narkotika ini sangat tinggi. Menurut Informan dengan inisial M teknik pembelian terselubung (undercover buy) ini pada prinsipnya penyidik akan berupaya menumbuhkan rasa kepercayaan dari para pengedar narkoba sehingga para pengedar tersebut tidak merasa curiga pada anggota kepolisian yang sedang melakukan penyamaran. Di sisi lain, dari segi jumlah barang bukti yang disita teknik ini juga sangat baik karena sasaran dari teknik ini adalah bandar, ${ }^{37}$ dengan tujuan untuk membongkar dan mengurai jaringan penyalahgunaan narkotika nya sehingga barang bukti yang disita sudah pasti lebih besar jumlah/ kuantitasnya dari pada menangkap pengguna saja.

\section{A. Hambatan pelaksanaan penyidikan tindak pidana narkotika menggunakan cara} undercover buy (pembelian terselubung) berdasarkan Undang-undang Nomor 35 Tahun 2009 tentang Narkotika.

\footnotetext{
${ }^{36}$ Hasil wawancara dengan Aiptu Candra, Katim Buser, Polsek Senapelan, 10 April 2019, Pukul 09.30 Wib bertempat di Polsek Senapelan

37 Hasil wawancara dengan informan inisial M, Polsek Senapelan, 18 Mei 2019, Pukul 15.10 Wib bertempat di Polsek Senapelan
} 
Berdasarkan hasil wawancara dengan Bripka Jatmiko salah satu metode dalam mengungkap kasus narkotika yang digunakan Sat Reskrim Polsek Senapelan dalam mengungkap penyalahgunaan narkotika, yaitu dengan metode pembelian terselubung (undercover buy), masih menemui kendala, yaitu:.

\section{Internal}

Kendala internal, antara lain:

a. Jumlah personil.yang ada saat ini di Polsek Senapelan masih belum memadai jika dilihat tinggi tindak pidana narkotika. Jumlah personil Unit Reskrim (di bagian Operasional) berjumlah 5 orang, sedangkan yang idealnya personil unit reskrim bagian Operasional berjumlah 8 orang.

b. Kekurangannya dana operasional, persoalan biaya pun tidak luput dari dari kendala yang di alami oleh Polsek Senapelan. Karena dalam mengungkapkan satu kasus kejahatan penyalahgunaan atau pengedar narkotika memakan waktu yang lama dan pihak Reskrim harus mengeluarkan banyak biaya. Dalam pembagian dana RAB (Rencana Anggaran Biaya) dari Mabes Polri, tiap Polsek mendapatkan biaya operasional dalam satu perkara narkotika sekitar Rp. 3.000.000 - Rp. 4.000.000. sementara untuk melakukan Operasional Penyelidikan hingga ke tingkat penyidikan membutuhkan biaya sekitar Rp. 5.000.000 - Rp. 6.000.000.

c. Kurangnya jumlah peralatan yang diperlukan dalam pelaksanaan metode pembelian Terselubung (Undercover Buy). Alat alat yang biasanya di gunakan untuk melakukan metode pembelian terselubung (undercover buy) seperti koneksi Cek Posisi ataupun alat untuk penyadapan panggilan yang alat tersebut tidak di miliki oleh Polsek Senapelan.

d. Anggota yang menyamar terkadang sudah dikenal oleh pengedar narkotika, misalnya pada saat melaksanakan kegiatan pengamanan atau tugas luar lain yang mengharuskan anggota kepolisian menggunakan seragam.

\section{Eksternal}

Menurut Aiptu Candra selaku Katim Buser, faktor-faktor eksternalnya adalah:

a. Kurangnya peran serta masyarakat. Peran serta masyarakat diatur dalam Pasal $104 \mathrm{~s} / \mathrm{d}$ 108 Undang-Undang Nomor 35 Tahun 2009 yang mana masyarakat mempunyai kesempatan yang seluas-luasnya untuk berperan serta membantu pencegahan dan pemberantasan penyalahgunaan dan peredaran narkotika dan prekursor narkotika. 
b. Dalam mendapatkan informan dalam melaksanakan teknik Undercover Buy, kepolisian perlu mendapatkan informasi awal tentang adanya peredaran gelap Narkotika. Hal ini pada beberapa kesempata sulit untuk didapatkan kepolisian. Hal itu terjadi antara lain, karena warga masyarakat masih terkesan takut dalam berurusan dengan kepolisian terutama dalam kasus pidana besar seperti Narkotika ini.

c. Menentukan lokasi pembelian terselubung. Dalam hal menentukan lokasi pembelian terselebung anggota kepolisian pada umumnya akan mengikuti tempat keinginan para pengedar narkotika dan pada saat itu lah tingkat penyelesaian teknik ini masuk dalam kategori sulit, karena pengedar akan memilih tempat yang telaPh dia kuasai daerah setempat.

d. Penyidik mendapat teror. Teror pasti dialami anggota yang akan melaksanakan penangkapan dengan teknik undercover buy ini, karena pada saat pelaksanaan nya pengedar akan berada pada posisi tertekan dan pada saat itulah anggota kepolisian yang sedang menyamar akan mendapatkan teror baik itu teror fisik/ baku hantam ataupun teror verbal yaitu dengan memaki atau hal yang lebih nekat lagi, contohnya seperti berteriak seolah anggota kepolisian adalah pencuri atau perampok.

e. Jaringan narkotika menggunakan tehnik ranjau, yang dimaksud teknik ranjau disini adalah para pengedar narkotika melakukan transaksi jual beli narkotika dengan calon pembeli melalui telepon seluler dan transaksi antar rekening bank, pengedar akan meletakkan narkoba tersebut di suatu tempat dan akan memberikan kabar kepada calon pembeli setelah barang tersebut telah diletakkan di suatu tempa. Pengedar akan sangat menghindari untuk bertemu secara langsung melakukan transaksi, terlebih lagi bertemu dengan calon pembeli yang baru. ${ }^{38}$

Berdasarkan hasil wawancara dengan Aiptu Candra, penggunaan metode pembelian terselubung (undercover buy) memiliki risiko tinggi, hal ini dikarenakan kebanyakan tempat pelaksanaan transaksi jual beli narkoba yang direncanakan oleh anggota kepolissan yang sedang menyamar dan pengedar narkotika sudah hampir dapat dipastikan merupakan daerah yang telah biasa dilintasi dan pengedar telah menguasai daerah tersebut yang tentu berisiko kepada keselamatan anggota kepolisian. Namun dalam hal ini Aiptu Candra meyakini bahwa

${ }^{38}$ Hasil wawancara dengan Aiptu Candra, Katim Buser, Polsek Senapelan, 10 April 2019, Pukul 09.30 Wib bertempat di Polsek Senapelan 
anggota Reskrim Polsek Senapelan tentu sudah mengerti, menguasai dan tanggap terhadap langkah-langkah yang harus dilakukan bilamana hal yang tidak diinginkan tersebut terjadi. ${ }^{39}$

Kendala lain dalam penggunaan metode pembelian terselubung (undercover buy) ini yang dilakukan oleh Reskrim Polsek Senapelan terkendala pada saat hendak melakukan suatu penyergapan atau penangkapan kepada bandar narkotika, berdasarkan Informan atau pihak yang bekerja sama dengan Reskrim Polsek Senapelan, pelaku bandar narkotika tersebut sulit untuk diajak bertemu dengan pembeli terselubung, karena Bandar narkotika tersebut kebanyakan hanya ingin menjual dan bertemu langsung melakukan transaksi narkotikanya dengan orang-orang yang biasa atau telah lama berlangganan dengannya, sehingga hal ini yang sulit membuat Reskrim Polsek Senapelan untuk melakukan penyergapan langsung dengan Bandar besar narkotikanya. ${ }^{40}$

Menurut Ipda Budi Winarko, ST langkah-langkah penyidikan tindak pidana narkotika di Polsek Senapelan, antara lain: ${ }^{41}$

a. Observasi

Observasi adalah mengamati, memperhatikan seseorang yang di yakini telah melakukan tindak pidana narkotika, baik orang tersebut sebagai pelaku (bandar) dan korban (pemakai) narkotika. Teknik observasi dilakukan pada saat operasi tindakan yang dilaksanakan dalam mencapai sasaran tertentu.

\section{b. Surveillance (pembuntutan)}

Surveillance adalah sebagai pengawasan terhadap orang, kendaraan, tempat / obyek yang dilaksanakan secara rahasia terus menerus / kadang-kadang berselang untuk memperoleh info tentang kegiatan dan identitas sasaran, dan merupakan salah satu teknik penyelidikan yang bisa dilaksanakan yang bertujuan untuk mengidentifikasi sumber, kurir dan penerima narkotika, serta jaringan / peredaran narkotika.

\section{c. Undercover Agent (Penyusupan Agen)}

Undercover Agent (UCA) adalah petugas yang melaksanakan tugasnya dengan menyamar atau berkedok dan bergerak terus-menerus dengan tujuan ; untuk dapat mengetahui suatu tindak pidana / kejahatan yang sedang direncanakan atau akan dilaksanakan dan siapa saja pelakunya, guna mendapatkan barang bukti, guna dapat mengetahui tempat penyimpanan /

\footnotetext{
39 Ibid

${ }^{40}$ Ibid

${ }^{41}$ Hasil wawancara dengan Ipda Budi Winarko, ST Kanit. Reskrim, Polsek Senapelan, 10 April 2019,
} Pukul 14.00 Wib bertempat di Polsek Senapelan 
penyembunyian barang bukti narkotika, menentukan saat yang tepat kapan dilakukan penindakan. Undercover agent dalam melakukan penyamaran bisa menjadi sebagai apa saja tergantung dengan situasi dan kondisi di lapangan.

d. Pembelian Terselubung (undercover buy)

Undercover buy merupakan suatu teknik khusus dalam penyelidikan dan penyidikan kejahatan narkotika, dimana seorang informan, anggota BNN/Polri, pejabat lain yang diperbantukan kepada BNN berada dibawah selubung bertindak sebagai pembeli dalam suatu transaksi gelap jual beli narkotika dengan maksud dapat menangkap bandar tersebut.

e. Penyerahan narkotika yang dikendalikan (controlled dellivery); ${ }^{42}$ Controlled Delivery merupakan suatu teknik khusus dalam penyidikan kejahatan Narkotika dan Psikotropika manakala pada tahap penyelidikan, terjadi penangguhan/ penangkapan/ penahanan/ pensitaan barang bukti, dimana seorang tersangka yang mau bekerjasama dengan polisi atau informan atau pejabat lain (undercover agent) dibenarkan/ Narkotika dan Psikotropika tersebut pada penerimanya, dengan maksud pada saat penerimaan dapat ditangkap orangorang yang terlibat kejahatan Narkotika dan Psikotropika beserta barang buktinya

B. Upaya yang dilakukan untuk mengatasi hambatan pelaksanaan penyidikan tindak pidana narkotika menggunakan cara undercover buy (pembelian terselubung) berdasarkan Undang-undang Nomor 35 Tahun 2009 tentang Narkotika.

Upaya yang dilakukan untuk mengatasi hambatan pelaksanaan penyidikan tindak pidana narkoba menggunakan cara undercover buy (pembelian terselubung) berdasarkan Undang-undang Nomor 35 Tahun 2009 tentang Narkotika : ${ }^{43}$

1. Penambahan personil penyidik tindak pidana narkotika merupakan tindak pidana yang sudah besar jaringannya baik secara nasional maupun internasional ,untuk itu diperlukan tenaga atau personil pihak kepolisian yang profesional untuk memberantas tindak pidana ini . Sampai saat ini personil masih dapat dikategorikan kurang. Hal ini mengakibatkan ketidakseimbangan dengan banyaknya kasus peredaran narkotika yang semakin hari semakin meningkat terutama di Polsek Senapelan.

2. Penambahan dana operasional, dimana Polsek Senapelan dalam penambahan dana operasional mengajukan kepada pemerintah khususnya Kapolri.

\footnotetext{
42 Ibid

${ }^{43}$ Hasil wawancara dengan Ipda Budi Winarko, Kanit. Reskrim, Pol Pukul 14.00 Wib bertempat di Polsek Senapelan
} 
3. Memaksimalkan peralatan yang tersedia, terhadap kendala kurangnya peralatan yang tersedia dalam melakukan penegakan hukum terhadap tindak pidana narkotika di Polsek Senapelan, sebaiknya pihak kepolisian mengambil upaya mengatasinya dengan lebih memaksimalkan setiap peralatan yang ada. Peralatan yang bisa disediakan antara lain kendaraan yang layak dan memenuhi kualifikasi untuk melakukan pengejaran bilamana jarak tempuh dan akurasi nya hal ini juga bertujuan untuk mencegah target yang berusaha melarikan diri agar dapat dilumpuhkan.

4. Mengajak seluruh komponen masyarakat untuk melakukan langkah-langkah kongkrit, dimulai dari lingkungan masing-masing karena kejahatan narkotika sudah bersifat transaksional, dengan jaringan global sehingga penegak hukum tidak dapat bekerja sendirian untuk membendung masuknya jaringan sindikat narkotika di wilayah Polsek Senapelan.

Berdasarkan keterangan di atas mengenai Peran dan Metode Pembelian Terselubung (Undercover Buy) dalam mengungkap tindak pidana penyalahgunaan narkotika oleh pihak kepolisian, sudah sesuai dengan SOP di mana para penyidik polri mampu mengungkap jaringan narkotika di wilayah hukumnya, namun masih perlu pembenahan terutama peralatan yang digunakan (senjata, kendaraan) dan sumber daya manusia yang ada.

Menurut Ipda Budi Winarko, ST upaya-upaya dilakukan oleh penyidik untuk mengatasi kendala internal adalah sebagai berikut $:^{44}$

1. Upaya mengatasi kekurangan peralatan yang diperlukan, adalah dengan mengupayakan penyidik dalam pengoptimalisasian kinerja yaitu dengan melakukan upaya memaksimalkan Sumber Daya Manusia agar dapat menggunakan peralatan yang dibutuhkan dalam penyidikan secara maksimal. Dalam rangka peningkatan Sumber Daya Manusia penyidik, polri telah mengupayakan melalui peningkatan intensitas kegiatan-kegiatan pelatihan penyidikan dalam melakukan tehnik-tehnik yang digunakan penyidik dalam tindak pidana narkotika serta memaksimalkan daya kerja anggota penyidik polri Direktorat Reserse Narkoba.

2. Upaya dalam mengatasi biaya operasional yang terbatas. Penyidikan suatu kasus narkoba yang dilakukan dengan tehnik pembelian terselubung (undercover buy)

${ }^{44}$ Hasil wawancara dengan Ipda Budi Winarko, ST Kanit. Reskrim, Polsek Senapelan, 10 April 2019, Pukul 14.00 Wib bertempat di Polsek Senapelan 
adalah dengan mengajukan rencana penambahan jumlah anggaran dengan harapan akan ditindaklanjuti langsung oleh bagian operasional.

3. Penyidik harus bersikap profesional. Penyidik yang yang akan melakukan tehnik pembelian terselubung (undercover buy) ini harus bersikap secara profesional dan hati-hati dalam menjalankan tugasnya, serta meminimalisir kesalahan atau bahkan jangan sampai melakukan kesalahan dalam tugas, karena hanya dengan sedikit kesalahan maka nyawa penyidik maupun anggota yang lain akan terancam bahaya atau operasi yang dilakukan akan gagal. Penyidik harus melakukannya sesuai dengan prosedur yang sudah ditetapkan oleh Polri agar tehindar dari bahaya, karena kesalahan yang dilakukanya apabila diketahui oleh anggota jaringan narkotika maka akan dimanfaatkan oleh jaringan tersebut, yang kemudian akan merugikan anggota serta penyidik itu sendiri. Profesionalisme adalah elemen terpenting dalam upaya untuk menanggulangi kendala-kendala yang ditimbulkan dalam melakukan pembelian terselubung (undercover buy) ini. Jika upaya-upaya untuk mengatasi kendala internal sudah dilakukan oleh Polri, yang kedua adalah upaya represif, yaitu polri dalam mengatasi jika suatu tindak pidana narkotika yang dilakukan dengan teknik pembelian terselubung (undercover buy) sudah terjadi. Adapun upaya-upaya penyidik untuk mengatasi kendala-kendala eksternal sebagai berikut $:^{45}$

1. Mendapatkan informan dan mengoptimalkan peran tersangka; upaya yang dimaksudkan dalam mengoptimalkan peran informan disini yaitu dengan mengumpulkan informasi dengan menggunakan informan (mata-mata) dan melakukan pembelian terselubung dengan menggunakan kurir atau tersangka yang telah tertangkap. Informan ini biasanya berada di dalam lingkungan atau komunitas yang akrab dengan penggunaan narkoba. Informan yang ini tentu tidak melaporkan begitu saja ke polisi secara cuma-cuma, tentu ada yang diinginkan oleh informan tersebut biasanya polisi melakukannya dengan iming-iming uang.

2. Upaya dalam menentkan lokasi pembelian terselubung, upaya yang dilakukan penyidik polri dalam menentukan lokasi perlu diperhatikan hal sebagai berikut:

${ }^{45} \mathrm{Ibid}$ 
a. Lokasi harus memungkinkan dilakukannya pengawasan lawan dan kemungkinan dilakukannya pengamanan terhadap pelaku undercover dalam melakukan transaksi dan menghindari tempat yang terlalu ramai dan terbuka.

a. Lokasi memungkinkan dipergunakan alat alat komunikasi dan deteksi baik untuk mengawasi lawan maupun untuk kepentingan komunikasi serta untuk koordinasi semua petugas.

b. Lokasi harus dikuasai sejak dini, sehingga memungkinkanya dilakukan usaha pengaman dan menghindari kontra penyelidikan pihak lawan.

Upaya yang dilakukan penyidik polri untuk mengatasi teknik ranjau ini dengan memanfaatkan kelemahan Teknik ranjau ini di mata hukum karena adanya Undang-Undang Narkotika tahun 2009 yaitu ada dalam pasal 86 ayat (2) tentang alat bukti yang sah. ${ }^{46}$ 


\section{Kesimpulan}

Berdasarkan pembahasan yang telah dijelaskan, maka pada bagian akhir ini dikemukakan kesimpulan yakni :

1. Keberhasilan metode pembelian perselubung (Undercover Buy) dalam mengungkap kasuskasus penyalahgunaan narkotika di wilayah hukum Polsek Senapelan, pembelian terselubung (undercover buy) ini haruslah dipersiapkan secara matang. Karena operasi ini merupakan operasi yang cukup berbahaya menyangkut nyawa dari orang yang terselubung. Kegagalan yang mengakibatkan kematian dari orang terselubung akan mengusik perasaan dari penyidik dan merupakan kegagalan bagi upaya penegakan hukum.

2. Hambatan pelaksanaan penyidikan tindak pidana narkoba menggunakan cara undercover buy (pembelian terselubung) berdasarkan Undang-Undang Nomor 35 Tahun 2009 tentang Narkotika di Lapangan Terkait Pelaksanaan Metode Pembelian Terselubung (Undercover Buy) Kendala internal antara lain: Jumlah personil, kurangnya jumlah peralatan yang diperlukan dalam pelaksanaan metode pembelian Terselubung (Undercover Buy) dan kendala eksternal antara lain : dalam mendapatkan informan/spionase, menentukan lokasi pembelian terselubung dan penyidik mendapat teror serta jaringan narkotika menggunakan teknik ranjau.

3. Upaya-upaya dilakukan oleh penyidik untuk mengatasi kendala internal adalah sebagai berikut : upaya dalam mengatasi kekurangan peralatan yang diperlukan, upaya dalam mengatasi biaya operasional yang terbatas, penyidik harus bersikap profesional. Adapun upaya-upaya penyidik untuk mengatasi kendala-kendala eksternal yaitu mendapatkan informan dan mengoptimalkan peran tersangka, upaya dalam menentkan lokasi pembelian terselubung 


\section{DAFTAR PUSTAKA}

Andi Hamzah, KUHP dan KUHAP, Jakarta: Rineka Cipta, 2007

A.R Sujono dan Bony Daniel, 2013, Komentar \& Pembahasan Undang-Undang Nomor 35 Tahun 2009 tentang Narkotika, Sinar Grafika : Jakarta, 2013.

Badan Narkotika Nasional, 2011, Pedoman Pencegahan Penyalahgunaan Narkoba Bagi Pemula, Jakarta: Badan Narkotika Nasional Republik Indonesia

BNN, "Materi Advokasi Pencegahan Narkoba”. Jakarta: BNN. 2005

Dikdik M. Arief Mansur \& Elisatris Gultom, Urgensi Perlindungan KorbanKejahatan (Antara Norma dan Realita), Jakarta : Raja Grafindo Persada, 2007

Hari Sasangka, 2003, Narkotika dan Psikotropika dalam Hukum Pidana, Bandung: Mandar Maju, 2003

I Putu Wisnu Nugraha, dkk. 2016, Peranan Teknik Undercover Buy Dalam Pengungkapan

Tindak Pidana Narkotika (Studi di Polresta Denpasar), Artikel, Fakultas Hukum Universitas Udayana, 2016

Laden Marpaung,, Proses Penanganan Perkara Pidana (penyelidikan dan penyidikan) edisi kedua,Jakarta: Sinar Grafika, 2011

Moh. Taufik Makaro, dkk. 2003, Tindak Pidana Narkotika, Ghalia Indonesia : Jakarta

Petunjuk Lapangan No. Pol. Juklap/04/VIII/1983, taktik dan teknik pembelian narkotika dan psikotropika

Ricky Gunawan, Kajian dan Anotasi Peradilan Putusan Ket San: Menelusuri Fenomena Penjebakan Dalam Kasus Narkotika, Dictum Edisi 1 - Oktober 2012

Siswanto, S. 2012, Politik Hukum Dalam Undang-Undang Narkotika, Cetakan Pertama, Rineka Cipta : Jakarta, 2012

Tim Penyusun Badan Narkotika Nasional Republik Indonesia, 2007, Pencegahan Penyalahgunaan Narkoba Sejak Dini, Jakarta : BNN RI

Wishnu Kurniawan dan Tanty Susanti, 2015, Penerapan Ultimum Remedium Terhadap Penanganan Tindak Pidana Narkoba (Studi Wilayah Polresta Barelang Batam), Journal of Judical Review Vol.XVII No.3 Desember 2015

Undang- Undang dasar 1945 dan perubahannya

Undang-Undang Nomor 35 Tahun 2009

https://www.rappler.com/indonesia/137677-pidato-jokowi-hari-anti-narkoba-internasional 
http://nasional.news.viva.co.id/news/read/516363-bnn--pengguna-narkoba-di-indonesiacapai-4-2-juta-orang 